\title{
Analysis on the Status Quo of the Document Resources Guarantee of the Key Subjects in Local Undergraduate Colleges and Universities
}

\author{
Li Shuang \\ Baicheng Normal University, Baicheng, China \\ lishuang329@163.com
}

Keywords: Undergraduate Colleges and Universities, Key Subjects, Document Resources Guarantee, Status Quo

\begin{abstract}
In recent years, the social economy of our country is developing at a high speed, many industries have ushered in new opportunities for development, and the development of industries can not be separated from the strength of talents, so these industries have a great demand for complex talents with high literacy and strong ability in development, which requires colleges and universities to attach importance to the construction and development of disciplines during the period of talent training, so as to provide a large number of high-quality talents for the society. During the construction of key subjects, schools need to rely on a large number of literature resources to provide them with support, to ensure that the construction of key subjects can be carried out with high quality, high efficiency for better training of subject talents. Based on this, this paper summarizes the relevant contents of literature resources guarantee, and analyzes the problems existing in the application of this kind of resources during the construction of key disciplines in many local universities and colleges. Combined with the specific problems, this paper puts forward several strategies to strengthen the construction of the document resources guarantee system in order to promote the construction of the document resources guarantee system in colleges and universities, so that students can consult the literature resources in the school library and improve their abilities in all aspects to become the useful talents of the society.
\end{abstract}

\section{Introduction}

Our country attaches great importance to the education of talents, and has continuously invested a large amount of funds and technology in the social and economic development to promote the orderly development of educational undertakings. Among them, colleges and universities have obtained sufficient development funds and technologies in the process to build a complete teaching place, equipped with modern teaching facilities, according to the different disciplines to train a lot of talents. After the strategy of rejuvenating the country through science and education was put forward, the education departments carried out the reform of colleges and universities in combination with policies and market development, upgraded and transformed a large number of applied colleges and universities, expanded the enrollment scale and increased, reduced and merged some disciplines of colleges and universities, so that colleges and universities can play a better role in teaching and educating people. In the course of practical development, these local colleges and universities often adopt the method of key discipline construction to develop education, in which literature resources play a very important role, but combined with the specific situation of the application of literature resources during the construction of many school subjects, it can be understood that the guarantee function provided by this kind of resources has not been brought into full play, which seriously hinders the effective development of the construction of key subjects in schools. Therefore, local colleges and universities need to fully recognize the status quo of literature resources construction in discipline construction, and then analyze the specific factors that lead to the occurrence of this situation so as to ensure the literature resources and realize the healthy development of the key subjects of the school. 


\section{Summary of Document Resources Guarantee}

The literature resources of colleges and universities are basically stored in the library of the school. The contents include the related literature resources of the subject set up in the school. The library needs to integrate all the literature resources in the library in the daily work and carry on the standardized management to provide inquiry, borrow service, exert the application value of literature resources, and improve the subject teaching and research effect continuously. However, in recent years, the ability of document resource management in the libraries of many local undergraduate colleges is poor, such as resource loss, damage, private gift or sale, etc., so the role of document resources protection is affected [1]. At present, many colleges and universities at home and abroad have carried out a large number of research on the library document resources security in the process of development, and have taken a variety of effective measures to ensure the document resources according to the current situation of the university to promote the library to collect scientific and reasonable literature resources of various disciplines, to build a scientific guarantee system, to continuously improve the library document resources support ability, and to provide help for the construction of key disciplines in schools.

\section{Problems about the Guarantee of Literature Resources in Local Undergraduate Colleges and Universities}

First of all, the number of literature resources is relatively small. There are many restricted factors in the development of key disciplines in local undergraduate colleges and universities. Many leaders do not attach importance to the document resources support work, who only apply the funds and technologies they have obtained to the construction and purchase of teaching buildings, instruments and equipment, etc. It is not recognized that the related key literature resources in the construction of key disciplines are the important driving factors for speeding up the construction of disciplines, so the quantity of literature resources procurement in schools is relatively small and the foundation is weak. At the same time, many local undergraduate colleges and universities are upgraded from specialized schools, whose own teaching level, academic atmosphere, quality of students is poor without awareness of consulting literature, and the existing literature is basically science and engineering literature, which is relatively old and few species, especially the lack of electronic literature resources. If teachers and students need to carry out related research, too few literature resources can not meet the needs of teachers and students. Therefore, less literature resources will affect the construction of key disciplines [2].

Secondly, we attach importance to discipline construction, resulting in less literature resources involved in key disciplines. Many colleges, which have just been transformed into undergraduate colleges, have formulated a development strategy for the future development of their schools at the early stage of development. However, the developers have failed to closely relate to the actual situation of their own schools and clearly define the orientation of running a school and carry out discipline construction. Instead, it advocates learning from other colleges and universities with high school quality and perfect discipline construction, which leads to more kinds of disciplines opened by the school, and the key subjects are not prominent. Although they have acquired literature resources, the resources that belong to each subject are few. As a result, it is difficult to effectively apply the limited literature resource funds to the construction of key disciplines and to guarantee the construction needs of key disciplines.

Thirdly, the document resources guarantee work lacks the reasonable management plan. In planning and managing library literature resources, local colleges and universities still use the traditional planning management method, which is purchasing resources only according to the quantity and type of resources on the purchase list. As a result, the rich diversity of resources is limited, and many resources are concentrated in some fixed disciplines, so the guarantee effect of resources is not ideal. At the same time, during the period of library resource management, there is no document resource guarantee plan for key discipline, the literature resource is basically theoretical content, lack of research resources to the subject problem [3]. 
Finally, the ability of the library document management personnel is low, lacks the specialized accomplishment. At present, many people who are in charge of literature resource management, purchasing, borrowing and lending work in the university library have poor professional accomplishment and weak sense of responsibility, which leads to the poor effect of the work. At the same time, with the development of computer technology and network technology, libraries also need to advance with the times to carry out electronic development, but many managers are older and not proficient in the computer operation of various resource management. The quality of the management work is not high. Therefore, the existence of the above problems has a lot of adverse effects on the document resources guarantee of key disciplines, which needs to be improved.

\section{The Strategy Analysis of Constructing the Document Resource Guarantee System}

\subsection{Enhancing the Attention of School Leaders to the Guarantee of Document Resources.}

Local undergraduate school leaders need to actively learn the successful experience and methods of discipline construction from other undergraduate schools of the same type, especially to learn the experience of carrying out the work of document resource guarantee, in order to realize the application value of the guarantee work. In order to actively cooperate with the development of literature resources in the construction of key disciplines, the school leaders should clarify the school orientation of their own schools, to vigorously build and develop superior disciplines, and carry out the construction of other disciplines simultaneously. On the basis of highlighting the key points, the scientific document resource purchase plan should be formulated, and the latest and most advanced research literature resources should be purchased according to the subject teaching and research needs, and the literature resource base should be expanded continuously. At the same time, during purchasing resource procurement, leaders need to increase the number and type of books purchased by allocating funds earmarked for the procurement of documentation resources on the basis of increased awareness, so that teachers and students in need can obtain the required literature resources in the library. In addition, leaders also need to promotion and education of all teachers and students, library administrators about the construction of key disciplines and the importance of document resources and other relevant contents, in order to promote all teachers and students in the school. All resource managers can enhance their knowledge and understanding of literature resources protection, and then it can continuously improve its management ability in practical work and create a good academic atmosphere in learning to stimulate the subjective initiative of teachers and students to effectively use literature resources to carry out learning research [4].

\subsection{Constructing a Perfect Document Resource Guarantee Mechanism.}

During the planning, management and purchasing of literature, local colleges and universities need to establish the corresponding guarantee mechanism to do the work well, which mainly includes the proportion of the expenditure of the annual literature resources procurement funds in the various disciplines in colleges and universities, the ratio of paper to electronic resources procurement, resource procurement and management requirements, management standards of electronic resource management systems, etc. According to the contents of the system, the managers can improve and improve the quality of the library literature resources, and provide sufficient and abundant resources for the construction and development of the key disciplines under the premise of improving the management ability. At the same time, there is a need to clear the structure and responsibility of personnel organization in the work of document resource guarantee, in which the work of resource guarantee can be handled by different managers of the library. If the workload is relatively large, it is possible to set up a group to deal with the problem. If any resource guarantee defect occurs during the guarantee management, it is possible to quickly find relevant personnel to deal with the problem according to the work arrangement, so as to avoid false prevarication, and resolutely prevent the manager from selling or renting the collection document resources to a place other than the school through the restriction of the system to construct a good environment for the realization of the document resource guarantee function. 


\subsection{Strengthening the Reasonable Purchase and Planning Management of Document Resources.}

First of all, in terms of resource procurement, library managers need to issue questionnaires on the resources required to teachers and students in key disciplines each year before books are purchased. Teachers and students are required to list the names of the resources expected of the school library according to the characteristics of the subject and the latest situation in the subject research. After the managers have recovered the questionnaires, they have removed the unqualified questionnaires. The contents of other questionnaires are arranged in a complete way, and through the network, experts and scholars in key disciplines are consulted to study the reasonableness of procurement resources. Managers are required to procure resources according to name. At the same time, managers need to record the time of purchase of books in the library on key subjects, assess the value of use, and, if the resources are old, place them in one place, and try to keep them up to date. The most advanced resources are placed in the most conspicuous areas, and the propaganda activities of the latest literature resources are strengthened in the school, so as to attract the attention of teachers and students, and make them make good use of the resources to do the research work of key subjects in time. In addition, managers should attach importance to the procurement and sharing of electronic resources. After purchasing part of electronic literature resources, university libraries can strengthen communication and contact with other school libraries, so as to realize the exchange of electronic resources. On the basis of saving the cost of purchasing literature resources, teachers and students can easily and quickly consult the electronic literature resources in quantity and variety through the Internet, and teachers and students do not need to go to the library and take direct access to the campus network free of charge when their study is tight [6].

Secondly, in the aspect of document resource management, the library needs to introduce modern management system, input the book information registered in the paper file into the system in time, and place the resources according to the differences of the subject and the different categories of the resources. It is convenient for teachers and students to check the storage place of resources through the operating system, and also convenient for managers to put back the returned document resources in time by combining the contents of the system records. At the same time, the system also needs to record the serious damage to the books, as well as the list of key subject resources that need to be purchased again and yet to be purchased. It is convenient for the school library to draw up the document purchase plan in the second year to determine the type and quantity of the purchasing resources by referring to the data retained in the system [7].

\subsection{Improving the Ability of Managers to Work.}

The procurement and management of literature resources in university libraries involve more complicated work and greater workload. After each purchase, more books are required to be sorted out and put on shelves, and in addition, when the teachers and students borrow literature resources, the staff should do well in the input and return of resources, which requires the staff to have a strong ability to work and a higher sense of responsibility. Therefore, first of all, the school library needs to recruit a group of managers with rich experience and ability in the management of literature resources in local undergraduate colleges and universities to obtain employment, and constantly optimize the working ability and level of all the library resource managers to build a professional management team to engage in resource management. Secondly, librarians should regularly invite experts and scholars from the management of literature resources to come to the school to conduct training and lectures on modern management concepts, techniques, electronic management and operation. In this way, managers can effectively apply the management knowledge they have learned in their daily management work. Finally, the library needs to set up an incentive mechanism, select a document resource management staff of high quality to give it a certain material reward every semester, so as to stimulate the enthusiasm of all the management staff. So that they can devote themselves to the concrete management work with full enthusiasm and give full play to the guarantee role of the literature resources in the construction of the key subjects of the school. 


\section{Conclusion}

At present, the construction of literature resources of the key subjects in local undergraduate colleges is not satisfactory, so it is necessary for the leaders of colleges and universities to strengthen their reflection in the course of development, so as to improve the guarantee effect of literature resources their ideological awareness from the aspects of ideology, system, procurement, management and personnel, so that teachers and students of key subjects can consult the related literature resources about teaching and project research through the school library to gradually improve the ability and standard of local colleges and universities.

\section{References}

[1] Li Wenyue. Analysis on the current situation of Local document resources guarantee system in Cangzhou [J]. Inner Mongolia Science Technology \& Economy, 2016(24):29-30.

[2] Jiang Yanbo, SHENG Xiuwen. Research on the construction of Regional document resources guarantee system of key subjects in local colleges and universities: a case study of Changbei university library alliance in Jiangxi Province [J]. Library and Information Service, 2015, 59(11): 89-93.

[3] Chen Hao. Research on the construction of document information guarantee system in private colleges and universities in Anhui province [D]. Anhui University, 2014.

[4] Li Xiao. Analysis on the status quo of the document Resources guarantee system in Beijing colleges and universities [J]. Journal of Library and Information Sciences in Agriculture, 2014, 26(03): 16-20.

[5] Liu Jiayin. A study on the comprehensive evaluation of the efficiency of digital resources utilization in domestic colleges and universities [D].Wuhan University, 2013.

[6] Gong Jian. The present situation and countermeasures of the construction of minority literature resources in the libraries of universities for nationalities and discussion about the construction of the guarantee system of the minority literature resources in China [J]. Journal of Guizhou University for nationalities (philosophy and Social Sciences Edition), 2012(06):143-146.

[7] Li Mianbin. The status quo and Development Countermeasures of the document Resources guarantee Construction in Colleges and Universities in Hainan Province [J]. Journal of Library and Information Sciences in Agriculture, 2012, 24(04):34-36+44. 